\title{
KOMUNIKASI POLITIK DAN KONFLIK DALAM KEBIJAKAN PEMERINTAH (Studi Kasus Konflik Kebijakan Antara Legislatif Dan Eksekutif Di Kabupaten Buton Selatan, Sulawesi Tenggara)
}

\author{
Ansar Suherman \\ Universitas Muhammadiyah Buton \\ Email: ansar.suherman@yahoo.co.id
}

\begin{abstract}
Executive policy-related polemics often leads to war of opinion that led to a conflict with the legislature, one of which is the formulation of the Draft Regulation (Ranperda) on Spatial Planning (Spatial) Buton Selatan Regency. This study aims to determine the pattern of the relationship between the executive and legislative communications along with constraints and problems encountered in the implementation of the authority and form of the conflict between the executive and the legislature in lawmaking Spatial Buton Selatan. The method used is qualitative approach. Data obtained directly by using interviews with informants about the conflict in political communication in addressing regional legislative policy as the executive regent Buton Selatan on Spatial Ranperda Buton Selatan. The data in thisstudy using the model data analysis komponensial (componential anaylisis). The results showed that the pattern of the relationship between the executive and legislative communication in conflict resolution in the determination of Buton Selatan Spatial regulation is through the process of formal organizational communication and informal organizational communication. Form of the conflict between the executive and the legislature in lawmaking Spatial Buton Selatan Regency is a conflict between organizations, between the executive and legislative of Buton Selatan Regency.
\end{abstract}

Keywords: Political Communication, Conflict, Policy, Executive, Legislative.

\section{PENDAHULUAN}

Sebagai daerah otonomi baru (DOB), Kabupaten Buton Selatan terus berupaya membenahi diri agar dapat bertahan sebagai daerah otonomi baru dan sejajar dengan daerah-daerah lainnya yang berada di sekitar Kabupaten Buton Selatan yang telah lebih dulu menjadi daerah otonom. Sebagai daerah baru, konflik sosial, konflik ekonomi, terlebih lagi konflik politik senantiasa hadir mewarnai proses pembangunan daerah ini. Konflik terjadi salahsatunya diakibatkan oleh tidak terjadinya komunikasi (misscommunication) yang baik antara pihak-pihak yang berkepentingan.

Konflik dalam komunikasi sering terjadi baik dalam hubungan interpersonal maupun kelompok atau organisasi. Adanya komunikasi dapat menyebabkan terjadinya konflik, tetapi di sisi lain, komunikasi yang terjadi itu sendiri dapat menjadi potensi terjadinya konflik. Timbulnya konflik atau pertentangan, merupakan suatu kelanjutan dari adanya komunikasi dan informasi yang tidak menemui sasarannya. Terjadinya konflik dalam setiap organisasi merupakan sesuatu hal yang tidak dapat dihindarkan. Hal ini terjadi karena di satu sisi orang-orang yang terlibat dalam organisasi mempunyai karakter, tujuan, visi, maupun gaya yang berbeda-beda. Di sisi lain adanya saling ketergantungan antara satu dengan yang lain yang menjadi karakter setiap organisasi. Tidak semua konflik merugikan organisasi. Konflik yang ditata dan dikendalikan dengan baik dapat menguntungkan organisasi sebagai suatu kesatuan. 
Dalam menata konflik dalam organisasi diperlukan keterbukaan, kesabaran serta kesadaran semua pihak yang terlibat maupun yang berkepentingan dengan konflik yang terjadi dalam organisasi. Hal seperti inilah yang merupakan persoalan yang sangat urgen dalam pembangunan demokrasi di daerah yaitu pengelolaan relasi kekuasaan kepala daerah dan DPRD. Berbagai polemik terkait kebijakan Bupati sering berujung pada perang opini di media massa dan pada rapat paripurna DPRD. Salah satunya adalah dalam perumusan Rancangan Peraturan Daerah (Ranperda) tentang Rencana Tata Ruang Wilayah (RTRW) Kabupaten Buton Selatan. Ranperda ini secara resmi diserahkan bersama delapan Ranperda lainnya oleh Bupati Buton Selatan kepada Ketua DPRD pada rapat Paripurna DPRD, 17 Januari 2015 di Gedung DPRD Buton Selatan. Hal demikian terjadi karena adanya kekuasaan politik yang dimiliki oleh eksekutif dan legislatif. Menurut Cangara (2009), kekuasaan politik adalah kemampuan untuk memengaruhi kebijaksanaan umum yang dilakukan oleh pemerintah, mulai dari proses pembentukan sampai pada akibat yang ditimbulkannya.

Hubungan eksekutif dan legislatif yang tidak menunjukkan sinyal positif disebabkan oleh keegoisan di masing-masing pihak dimana mereka sama-sama merasa mempunyai legitimasi yang kuat karena dipilih langsung oleh rakyat. Eksekutif dan legislatif, dua lembaga pemerintahan yang kalau kita pahami secara normatif memiliki perbedaan kubu di masing-masing lembaga, lembaga eksekutif yang merepresentatifkan pemerintah dan lembaga legislatif yang merepresentatifkan masyarakat sebagai lembaga perwakilan. Sehingga menarik kemudian untuk dicermati, bagaimana konflik dan komunikasi politik legislatif dalam menyikapi kebijakan Bupati Buton Selatan selaku eksekutif tentang Ranperda RTRW Kabupaten Buton Selatan sebagaimana tujuan dari penelitian ini yakni untuk mengetahui pola hubungan komunikasi antara eksekutif dan legislatif beserta kendala dan masalah yang dihadapi dalam pelaksanaan kewenangan dan bentuk konflik yang terjadi antara eksekutif dan legislatif dalam penyusunan Perda RTRW Kabupaten Buton Selatan.

\section{BAHAN DAN METODE}

\section{Lokasi Penelitian}

Penelitian dilakukan disalah satu daerah otonomi baru di Provinsi Sulawesi Tenggara yakni Kabupaten Buton Selatan.

\section{Desain dan Variabel Penelitian}

Tipe penelitian ini bersifat kualitatif. Penelitian kualitatif dari sisi definisi dikemukakan oleh Moleong (2009), bahwa hal itu merupakan penelitian yang memanfaatkan wawancara terbuka untuk menelaah dan memahami sikap, pandangan, perasaan, dan perilaku individu atau sekelompok orang.

Dalam penelitian ini terdapat dua variabel yaitu: konflik dalam komunikasi politik antara eksekutif dan legislatif, dan variabel menyikapi Rencana Tata Ruang Wilayah (RTRW) Kabupaten Buton Selatan.

\section{Populasi dan Sampel}

Populasi dalam penelitian ini populasi dalam penelitian ini pihak eksekutif dan legislatif daerah Kabupaten Buton Selatan. Informan diambil dengan menggunakan teknik purposive sampling. Teknik penarikan sampel menggunakan sampling purposive, yaitu teknik penentuan sampel dengan pertimbangan tertentu (Sugiyono, 2011). Sampel dalam 
penelitian ini adalah Bupati Buton Selatan beserta Dinas Tata Ruang (Kepala Seksi Perencanaan Tata ruang) sebagai eksekutif, Dewan Perwakilan Rakyat Daerah (DPRD) Kabupaten Buton Selatan selaku legislatif dalam hal ini Panitia Khusus (Pansus) yang dibentuk dalam pembahasan Ranperda RTRW Kabupaten Buton Selatan, Badan Perencana Pembangunan Daerah (BAPPEDA)Kabupaten Buton Selatan, dan para tokoh masyarakat atau para pakar di bidang pengembangan dan penataan ruang.

\section{Pengumpulan Data}

Data dalam penelitian ini diperoleh melalui wawancara (interview) dan observasi yaitu mengumpulkan data di lapangan dengan mengadakan pengamatan langsung terhadap informan dalam aktifitasnya.

\section{Analisis Data}

Penelitian ini menggunakan teknik analisis data model komponensial (componential anaylisis).Menurut Bungin (2009) teknik analisa data ini menggunakan "pendekatan kontras antarelemen". Teknik ini digunakan untuk menganalisa unsur-unsur yang memiliki hubungan-hubungan yang kontras satu sama lain dalam domain-domain yang telah ditentukan untuk dianalisa secara lebih terperinci.

\section{HASIL PENELITIAN}

Pola hubungan komunikasi antara eksekutif dan legislatif dalam penyelesaian konflik dalam penetapan Peraturan Daerah (Perda) tentang Rencana Tata Ruang dan Wilayah (RTRW)Kabupaten Buton Selatan yaitu melalui proses komunikasi organisasi formal dan komunikasi organisasi informal.

Berdasarkan hasil analisis terhadap jawaban informan berupa unsur-unsur yang memiliki hubungan-hubungan yang kontras satu sama lain maka ditemukan bahwa kendala dan masalah yang dihadapi dalam pelaksanaan kewenangan antara eksekutif dan legislatif daerah Kabupaten Buton Selatan dalam pembahasan Perda RTRW yaitu dalam perumusan Perda ini dan kecenderungan untuk mendahulukan kepentingan pribadi masih dominan sehingga terjadi konflik kepentingan. Selain itu kerancuan data yang dituangkan eksekutif dalam draft Naskah Akademis RTRW sehingga legislatif menganggap bahwa materi dari Naskah Akademis yang akan dibahas di Pansus masih bersifat umum, bukan subtantif sesuai dengan kondisi wilayah Kabupaten Buton Selatan. Kerancuan ini terjadi karena kapasitas yang dimiliki eksekutif saat pengajuan rancangan ini kepada legislatif ditambah kemudian ketidakpahaman pihak eksekutif mengenai RTRW. Kurangnya pemahaman legislatif terhadap RTRW sehingga tidak ada tanggapan kritis dari legislatif dalam perumusan ini.

Upaya untuk meningkatkan hubungan kerja antara eksekutif dan legislatif daerah Kabupaten Buton Selatan dalam pembahasan Peraturan Daerah RTRW yaitu dengan mengesampingkan kepentingan-kepentingan individual dan mengutamakan kepentingan masyarakat. Salin menunjang antara keduanya diperlukan demi kelancaran pembangunan termasuk dalam pembahasan Rencana Tata Ruang Wilayah berupa sharing informasi terkait tata ruang demi kelancaran pembahasan Ranperda pada sidang Panitia Khusus, perlunya peningkatan sumber daya manusia dan mengumpulkan data-data otentik yang menggambarkan karakteristik Kabupaten Buton Selatan dari semua SKPD untuk pembenahan draft Naskah Akademis.

Bentuk konflik yang terjadi antara eksekutif dan legislatif dalam penyusunan Perda RTRW Kabupaten Buton Selatan adalah konflik antarorganisasi yang disebabkan oleh 
penentuan zonasi dalam tatanan kebandarudaraan yaitu sistem jaringan transportasi udara berupa lokasi pembangunan bandar udara, perbedaan luasan hutan lindung dalam RTRW Provinsi dan luas hutan lindung Kabupaten Buton Selatan, pengembangan wilayah kota berupa kawasan metropolitan center/kawasan kota baru dengan konsep waterfront city, dan ruang terbuka hijau.

\section{PEMBAHASAN}

Penelitian ini menunjukkan bahwa pola hubungan komunikasi antara eksekutif dan legislatif daerah Kabupaten Buton Selatan berupa komunikasi organisasi formal dan komunikasi organisasi informal. Pace dan Faules (2006) mengatakan bahwa komunikasi organisasi berdasarkan bentuknya dibagi menjadi organisasi formal dan informal. Komunikasi organisasi formal ialah komunikasi resmi yang menempuh jaringan organisasi struktur formal, mengikuti rantai komando yang dicapai oleh hirarki wewenang. Ciri-ciri suatu organisasi formal berkaitan dengan suatu fenomena yang disebut komunikasi jabatan (posisitional communication).

Hubugan dibentuk antara jabatan-jabatan, bukan antara orang-orang. Proses komunikasi tersebut merupakan aktivitas politik, menurut Piliang (2005) aktifitas politik adalah aktivitas konkret yang melibatkan di dalamnya berbagai tindakan politik berupa interaksi fisikal dan tubuh (bodily) di antaranya berbagai aktor politik. Akan tetapi, politik sekaligus adalah aktivitas abstrak, yang dibaliknya beroperasi ide, gagasan, atau keyakinan-keyakinan tertentu, yang disebut ideologi politik.

Pembahasan Rancangan Peraturan Daerah tentang Rencana Tata Ruang dan Wilayah RTRW Kabupaten Buton Selatan melalui rapat Panitia Khusus (Pansus) diwarnai oleh perselisihan pendapat, berbagai ide dan argumentasi antara eksekutif dan legislatif walaupun pada akhirnya didapatkan titik kesepakatan sehingga ditetapkan menjadi Perda RTRW Kabupaten Buton Selatan. Aktivitas tersebut seperti yang Nimmo (2004) melukiskan dengan singkat bahwa politik adalah pembicaraan, atau kegiatan politik adalah berbicara. Politik pada hakekatnya kegiatan orang secara kolektif sangat mengatur perbuatan mereka di dalam kondisi konflik sosial.

Namun konflik antara kedua lembaga tersebut dengan alasan rasional akan menjadi sebuah konflik fungsional tetapi sebuah konflik yang semula dianggap fungsional tiba-tiba bisa berubah menjadi disfungsional, misalnya karena ada sebagian pihak yang merasa lelah dan tidak lagi punya energi untuk terus-menerus bersaing dengan pihak lain. Hal ini perlu mendapat perhatian karena konflik biasanya melibatkan emosi sehingga menyelesaikan konflik disfungsional jauh lebih sulit ketimbang menciptakan konflik fungsional. Menurut Sobirin (2012), membiarkan konflik berarti membiarkan dirinya terperangkap ke dalam konflik. Sekalipun konflik fungsional, tetap harus dikelola sebab perbedaan antara konflik funsional dengan disfungsional begitu tipis.

Penanganan konflik antara eksekutif dan legislatif terjadi dalam dua cara berikut yaitu berkompromi dan mengintegrasikan. Dalam berkompromi (compromisting-CO), individu-individu berusaha untuk menemukan jalan tengah untuk mengatasi jalan buntu dan menggunakan pendekatan memberi-menerima sehingga kompromi dapat dicapai. Gaya mengintegrasikan (intergrating-IN) digunakan untuk menemukan solusi masalah, sebagaimana yang diungkapkan oleh Kreitner dan Kinicki dalam Pace dan Faules (2006).

Namun pendapat berbeda dikemukakan oleh nara sumber sebagai pakar RTRW dalam pembahasan Ranperda tersebut bahwa konflik antara keduanya diselesaikan dengan akomodasi pasif yang disebabkan oleh kurangnya pemahaman legislatif sehingga tidak ada tanggapan kritis dalam perumusan ini, begitu pula dengan pemerintah daerah. Kreitner dan Kinicki mendefinisikan bahwa gaya menurut (obliging-OB) mencakup akomodasi pasif 
yang berusaha memuaskan kebutuhan orang lain atau sepakat dengan saran-saran dari orang lain.

Penelitian yang sama pernah dilakukan oleh Hulukati (2008) dengan judul Dinamika Konflik Legislatif dan Eksekutif dalam Pengawasan Pembangunan di Provinsi Gorontalo. Hasil penelitian berkesimpulan konflik legislatif dan eksekutif terjadi karena prosedur pelaksanaanya yang tidak obyektif. Terlihat jenis kegiatan yang menjadi sumber konflik, umumnya menyangkut pekerjaan fisik dimana Pemerintah Kabupten/Kota mempunyai hak otonomi untuk kegiatan semacam itu. Diketahui pula secara tekhnis operasional, masih banyak anggota DPRD yang belum memahami kegiatan secara detail dari masing-masing SKPD, ketidakpahaman inilah yang sering menimbulkan konflik.

Demikian halnya dengan Pembahasan RTRW Kabupaten Buton Selatan terjadi kerancuan data yang dituangkan Pemda dalam draft Naskah Akademis RTRW. Kerancuan ini terjadi karena kapasitas yang dimiliki eksekutif saat pengajuan rancangan ini kepada legislatif ditambah kemudian ketidakpahaman pihak eksekutif mengenai RTRW. Kurangnya pemahaman legislatif terhadap RTRW sehingga tidak ada tanggapan kritis dari legislatif dalam perumusan ini. Pembahasan RTRW Kabupaten Buton Selatan adalah aktivitas politik berupa pembicaraan politik yang banyak menimbulkan konflik. Pendekatan strategi pengelolaan konflik yang paling sering digunakan adalah teori permainan (game theory). Pendekatan ini berbasis pada analisis terhadap tujuan akhir yang dikehendaki oleh pihak-pihak yang bersengketa. Teori ini berasumsi bahwa: semua aktor rasional; semua aktor tahu apa yang mereka akan lakukan; dan, "permainan" ini dapat diperagakan beberapa kali (Liliweri, 2011).

Bentuk konflik yang terjadi antara eksekutif dan legislatif dalam penyusunan Perda RTRW Kabupaten Buton Selatan adalah konflik antarorganisasi yang disebabkan oleh penentuan zonasi dalam tatanan kebandarudaraan yaitu sistem jaringan transportasi udara berupa lokasi pembangunan bandar udara, perbedaan luasan hutan lindung dalam RTRW Provinsi dan luas hutan lindung Kabupaten Buton Selatan,pengembangan wilayah kota berupa kawasan metropolitan center/kawasan kota baru dengan konsep waterfront city, dan ruang terbuka hijau.

Apa hubungan hal ini dengan komunikasi politik? Bagi Stephenson dalam Nimmo (2004), banyak sekali. Politik dari titik pandang publik dilihatnya sebagai permainan: "Para diplomat dan politikus melakukan pekerjaannya; publik hanya mempunyai sesuatu yang diberikan kepada politik untuk dibicarakan, untuk memberi kesenangan berkomunikasi kepada mereka." Ilmuwan politik Murray Edelman,dalam membedakan semantik dan estetik informasi, mengemukakan bahwa akibat komunikasi politik massa adalah terutama permainan. Informasi politik semantik itu berfaedah: ia dirancang untuk memajukan suatu kepentingan, untuk mencapai tujuan kebijakan.

\section{KESIMPULAN DAN SARAN}

Pola hubungan komunikasi antara eksekutif dan legislatif dalam penyelesaian konflik dalam penetapan Perda RTRW Kabupaten Buton Selatan yaitu melalui proses komunikasi organisasi formal dan komunikasi organisasi informal. Bentuk konflik yang terjadi antara eksekutif dan legislatif dalam penyusunan Perda RTRWKabupaten Buton Selatan adalah konflik antarorganisasi, yakni antara lembaga eksekutif dan legislatif Kabupaten Buton Selatan. Kendala dan masalah yang dihadapi dalam pelaksanaan kewenangan dan upaya yang dilakukan untuk meningkatkan hubungan kerja antara eksekutif dan legislatif daerah Kabupaten Buton Selatan dalam pembahasan Perda RTRW diantaranya adalah kerancuan data yang dituangkan eksekutif dalam draft Naskah Akademis RTRW dan kurangnya pemahaman legislative terhadap RTRW sehingga tidak 
ada tanggapan kritis dari legislatif dalam perumusan ini. Sedangkan upaya untuk meningkatkan hubungan kerja antara eksekutif danlegislatif daerah Kabupaten Buton Selatan dalam pembahasan Perda RTRW yaitudengan mengesampingkan kepentingankepentingan individual dan mengutamakan kepentingan masyarakatOleh karena itu, untuk membangun hubungan kemitraan antara eksekutif danlegislatif maka diharapkan kepada kedua lembaga tersebut sama-sama memposisikandiri sebagai mitra sekerja dalam membuat kebijakan daerah untuk melaksanakan otonomi daerah sesuai dengan fungsi masing-masing sehingga antar kedua lembaga itu membangun suatu hubungan kerja yang sifatnya saling mendukung bukan merupakan lawan ataupun pesaing satu sama lain dalam pelaksanaaan kewenangan.

\section{DAFTAR PUSTAKA}

Bungin, Burhan. (2009). Penelitian Kualitatif: Komunikasi, Ekonomi, KebijakanPublik, dan Ilmu Sosial Lainnya. Jakarta: Prenada Media.

Cangara, Hafied. (2009). Komunikasi Politik: Konsep, Teori, dan Strategi. Jakarta: Rajawali Pers.

Hulukati, Faizal. (2008). Dinamika Konflik Legislatif dan Eksekutif dalamPengawasan Pembangunan di Provinsi Gorontalo. Tesis. Yogyakarta:Administrasi Negara Universitas Gadjah Mada.

Liliweri, Alo. (2011). Komunikasi, Serba Ada Serba Makna. Jakarta: Kencana.

Moleong, Lexy J. 2009. Metodologi Penelitian Kualitatif. Bandung: RemajaRosdakarya.

Nimmo, Dan. (2004). Kominikasi Politik: Komunikator, Pesan dan Media. Bandung: Rosdakarya.

Pace R. Wayne dan Faules Don F. (2006). Komunikasi Organisasi: StrategiMeningkatkan Kinerja Perusahaan. Bandung: Rosdakarya.

Piliang, Yasraf A. (2005). Transpolitika: Dinamika Politik di dalam Era Virtualitas.Yogyakarta: Jalasutra.

Sobirin, Achmad. (2012). Perilaku Organisasi. Tangerang Selatan: Universitas Terbuka.

Sugiyono. (2011). Metode Penelitian Kuantitatif, Kualitatif dan $R \& D$. Bandung: Alfabeta. 